\title{
COMMENT
}

\section{Lost in translation}

\author{
Gregory A Petsko*
}

Francis Collins, the current director of the NIH (who, I might add, has got off to an excellent start), made a somewhat provocative remark after assuming his new position last year. Interviewed for The New York Times last October (5 October 2009; http://www.nytimes. com/2009/10/06/health/06nih.html?pagewanted=all), Collins is quoted as saying, "We're not the National Institutes of Basic Sciences, we're the National Institutes of Health." This remark came in the context of Collins' declared wish to encourage academic researchers to consider commercializing their ideas or pursuing drug development in universities, given the increasingly barren state of pharmaceutical company labs.

This reminded me of an article I read some time ago, which I largely agreed with but which made me hopping mad at the same time. It was 'Big biology is here to stay' by Steven Wiley, a Pacific Northwest National Laboratory Fellow and director of PNNL's Biomolecular Systems Initiative, which appeared in the The Scientist (http:// www.the-scientist.com/article/display/54854). Subtitled 'Why R01-funded biologists should throw their support behind large-scale science projects', the thesis of the article was that, "The business of the National Institutes of Health (NIH) is to fund research that improves people's health, not fund our personal research projects." In the article Wiley confesses that he originally thought the Human Genome Project would be a waste of money, but now thinks "we were all wrong". He goes on to say that, "Starting new, large-scale research projects was a clear demonstration that $\mathrm{NIH}$ was willing to try new approaches to accelerate biomedical research... trying to shift funds away from these large projects will ensure that they do fail, and will be self-defeating in the long run. We'd better hope these projects are successful, and we should do all we can to help them."

Now, given my well known views on the ascendancy of big science over little science, and the increasing tendency to direct research from the top down by bureaucratically initiated programs, you may be wondering why

*Correspondence: petsko@brandeis.edu

Rosenstiel Basic Medical Sciences Research Center, Brandeis University, Waltham, MA 02454-9110, USA
I say that I largely agree with Wiley's sentiments. The reason is that neither Wiley's column nor Collins' remark was really about big science in the sense that I mean it. I dislike large-scale, top-down programs; they are referring to projects aimed at translating the findings of biomedical research into therapies for human disease. Many of the big science projects that I regard as not worth continuing, like the structural genomics initiative, aim to advance fundamental knowledge rather than produce direct health benefits, and many of the others, like the effort to associate common genomic polymorphisms with risk for disease, are simply not likely to produce significant health benefits no matter what their intention was.

I have no problem with good science, whether it's large or small, although I do believe we must always have both sizes, and that research driven by the curiosity of the individual investigator should be the predominant kind we support. I agreed with Wiley (and Collins) because they were in fact making a case for good science aimed directly at finding cures versus science aimed at expanding our basic knowledge of biology - in other words, translational research versus basic research. And that is also precisely why the Wiley article (and the Collins remark) made me angry. It wasn't what they said. It was the way they chose to talk about it.

I hate translational research. Now, before you either applaud or burst a blood vessel, you should know something else: I also hate basic research. Or, to be precise, I hate the terms 'translational research' and 'basic research'.

If there's a theme, besides the transformative nature of the age of genomics, that runs through the columns I've written for the past 10 years, it's that the words we use to describe something are incredibly important, and often get us into all kinds of trouble. We should never have used 'therapeutic cloning' to describe somatic cell nuclear transfer; having the word 'cloning' in there allowed religious fundamentalists to define the terms of the debate about embryonic stem cells. We should not have let the term 'chemical' become a pejorative. 'Global warming' is a poor phrase to rouse people to change their way of life - 'climate crisis' might have been much better (and also would have had the virtue of being alliterative). But of all the poorly chosen words in recent scientific history, few are as bad as 'translational research' and 'basic research'. 
How did we allow this purely artificial distinction to dominate our discussion of funding priorities? It's everything we should avoid. It sets up a dichotomy that is bound to confuse the lay public; it divides us into two warring camps, competing for attention and resources; and it implies, falsely, that there may be a difference in value in the kind of work that we do based on its intent.

We should make this our mantra as life scientists: there is no such thing as basic research and no such thing as translational research. There is only research, period. If we must put an adjective in front of it, then let's use 'biomedical'. But we simply have to stop talking about our science as though there were different versions of it, with different objectives and different implicit worth.

Do you really think that what is called basic research could exist if the public, and its elected officials, did not believe they would ultimately derive some benefit from it? And what would translational research have to translate if no new fundamental discoveries were made? These two feuding city-states need each other, and ought to be united in common cause against the invading empire of ignorance, superstition, and anti-intellectualism. But more than that: they shouldn't be separate states in the first place.

We simply have to stop talking about research as though there were two kinds. There aren't. When we start to use those divisive terms, we have to check ourselves. When a scientific official like Francis Collins uses them, we have to urge him not to. And we have to make peace within our own community, with both sides in the current dispute recognizing not only that they need each other to survive, but that our enterprise is seamless - a continuum from the most basic discovery to its most practical application. If Barnett Rosenberg hadn't wondered what would happen to Escherichia coli cells when they were placed in an electric field, we would never have known that cisplatin, which doesn't have a single atom of carbon in it, was a drug that could block cell growth and division. But if a number of other scientists hadn't worked with him to follow the implications of that observation and test cisplatin on cancer models in animals, and then to fight for its eventual testing on people, testicular cancer would not be a curable disease, and Lance Armstrong would probably be dead. There is no basic research and no translational research; there is only research, in all its frustrating, expensive, confusing magnificence. Why should we take one of the greatest monuments to the human spirit and turn it into the Balkans?

But if you agree with me, and I hope you do, you are probably wondering, "Well how, then, can we explain to the public that you have to support the Barney Rosenbergs of the world doing things just to satisfy their own curiosity in order to get the cures you want? At least the way Collins and Wiley talk about research, you can piggyback support for basic research onto the flood of money coming in for translating discoveries into therapies. If you can't talk about the two parts of the enterprise that way, how do you get support for it at all?"

The answer, I think, is that we haven't been making the argument for the support of biomedical research as well as we could. Wiley is wrong when he says, "The business of the NIH is to fund research that improves people's health, not fund our personal research projects." The business of the NIH is to fund both, because they are the same thing. But how do we get that point across? Next month, I'll tell you.

Published: 26 February 2010

doi:10.1186/gb-2010-11-2-107

Cite this article as: Petsko GA: Lost in translation. Genome Biology 2010, 11:107. 